\title{
Protamine sulfate as an effective alternative to polybrene in retroviral-mediated gene-transfer: implications for human gene therapy
}

\author{
Kenneth Cornetta and W. French Anderson \\ Laboratory of Molecular Hematology, National Heart, Lung and Blood Institute, National Institutes \\ of Health, Bethesda, Maryland, U.S.A.
}

(Accepted 10 October 1988)

\section{Summary}

The polycation protamine sulfate was compared to polybrene, the usual agent employed, for its ability to increase the efficiency of retroviral infection. The murine retroviral vector $S A X$, which contains the neo ${ }^{R}$ gene and the human adenosine deaminase (ADA) cDNA, was used as a marker of cell infection. SAX viral supernate was titered on NIH 3T3 cells in varying concentrations of polycation. The highest infection efficiency for protamine was seen at $5 \mu \mathrm{g} / \mathrm{ml}$ and was 7 -fold greater than infections performed in the absence of polycation. Infection efficiency using protamine averaged $92 \% \pm 11$ (SEM) of the highest efficiency obtained with polybrene. Total ADA activity attained when human-ADA deficient $T$ cells were exposed to SAX supernate in the presence of protamine was $83 \%$ of that attained with polybrene. The infection rate of mouse bone marrow early progenitor cells (CFU-S) was similar with each polycation. In summary, for supernate infections, concentrations of 5-10 $\mu \mathrm{g} / \mathrm{ml}$ of protamine provided essentially the same infection efficiency as polybrene with low toxicity on a range of cell types. Since protamine is approved for human use by the U.S. Food and Drug Administration it provides an effective alternative to polybrene when developing human gene therapy protocols.

Protamine sulfate; Retroviral-mediated gene-transfer; Human gene therapy

Correspondence to: W.F. Anderson M.D., Bldg. 10, Rm 7D-18, National Institutes of Health, 9000 Rockville Pike, Bethesda, MD 20892, U.S.A. 


\section{Introduction}

Polycations are useful in improving the infection efficiency of murine retroviruses (Duc-Nguyen 1968). Polybrene has proven useful because of its efficacy and low toxicity (Manning et al., 1971) and is commonly used in retroviral-mediated gene transfer. Unfortunately, polybrene is not currently approved for human use. We evaluated the polycation protamine sulfate, currently approved for the treatment of heparin overdosage, as a possible substitute for polybrene in human gene therapy protocols. Expression of the retroviral vector SAX, which contains the bacterial gene for neomycin resistancc $\left(\right.$ neo $\left.^{\mathrm{R}}\right)$ and the human adenosine deaminase (ADA) cDNA, was used as an indicator of retroviral infection. This report examines our findings on the efficiency of retroviral-mediated gene-transfer at different concentrations of polybrene and protamine in mouse 3T3 fibroblasts, human $\mathrm{T}$ lymphocytes and mouse bone marrow early progenitors, colony forming units-spleen (CFU-S).

\section{Materials and Methods}

\section{Vector}

The retroviral vectors used in this study, SAX and N2 (Fig. 1), have been described previously. The $\mathrm{N} 2$ vector was derived from the Moloney murine leukemia virus by deleting the pol, env and most of the gag sequences and substituting the bacterial gene for neomycin resistance (Gilboa et al., 1986; Armentano et al., 1987). $\mathrm{SAX}$ is a derivative of the $\mathrm{N} 2$ vector with the insertion of a $1.7 \mathrm{~kb}$ fragment containing the SV40 early promoter and human ADA cDNA into the XhoI site (Kantoff et al., 1986). N2 is packaged by the ecotropic packaging cell line $\psi-2$ (Mann et al., 1983) with an average titer of $1 \times 10^{6} \mathrm{CFU} / \mathrm{ml}$. SAX is amphotropically packaged by the PA12 cell line (Miller and Buttimore, 1986) yielding an average titer of $5 \times 10^{6} \mathrm{CFU} / \mathrm{ml}$. Producer cell lincs werc maintained in Dulbccco's modified Eagle's medium with $10 \%$ fetal calf serum (FCS) and $2 \mathrm{mM}$ L-glutamine (D10)

N2

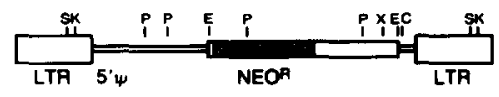

SAX

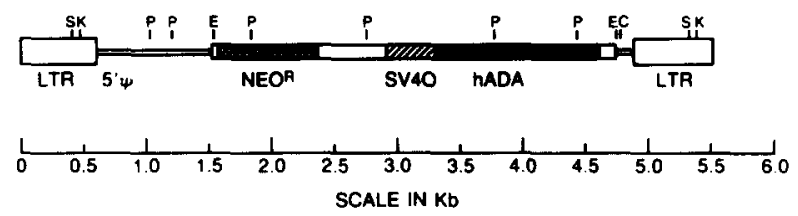

Fig. 1. The retroviral vectors N2 and SAX. LTR: long terminal repeat; $5^{\prime}$ : retroviral $5^{\prime}$ splice donor site; $\psi$ : viral packaging signal; $\mathrm{NEO}^{\mathrm{R}}$ : neomycin resistance gene from $\mathrm{Tn} 5$ transposon (cross hatching represents coding sequence); SV40: $K$ pnI-HindIII fragment of the SV40 early promoter; hADA: hu-

man ADA cDNA. Restriction sites: S, SacI; K, KpnI; P, PstI; X, XhoI; C, ClaI; E, EcoRI. 
with $400 \mu \mathrm{g} / \mathrm{ml}$ of active G418 (Gibco). All cells were incubated at $37^{\circ} \mathrm{C}, 5 \% \mathrm{CO}_{2}$. Viral supernates were collected from confluent dishes of producer cells $20 \mathrm{~h}$ after the addition of D10 media without G418. Viral titer is determined in the manner described under 3T3 infection (see below) using $8 \mu \mathrm{g} / \mathrm{ml}$ of polybrene (Aldrich, Milwaukee, WI).

3 T3 infection NIH 3T3, maintained in D10, were plated at a density of $1 \times 10^{5}$ celli per $60 \mathrm{~mm}$ dish $24 \mathrm{~h}$ prior to infection. Serial dilution of SAX supernate was prepared $\left(0,10^{-2}, 10^{-4}, 10^{-6}\right)$ and $1 \mathrm{ml}$ was added per dish. Polybrene or protamine sulfate (Lilly, Indianapolis, IN) was then added at the desired concentration and cells were incubated at $37^{\circ} \mathrm{C}, 5 \% \mathrm{CO}_{2}$ for $2 \mathrm{~h}$. Viral supernate was removed, replaced with D10, and cells were returned to the incubator. After $24 \mathrm{~h}, \mathrm{D} 10 \mathrm{me}-$ dium containing $400 \mu \mathrm{g} / \mathrm{ml}$ of $\mathrm{G} 418$ was added. G418 resistance colonies were scored 12-14 days after infection by staining plates with methylene blue.

ADA-deficient $T$ cells The ADA-deficient $\mathrm{T}$ cell line, TJF-2, was established by the procedure of Mitsuya et al. (1984) and has been described in detail elsewhere (Kantoff et al., 1986). TJF-2 cells were maintained in RPMI 1640 medium with $10 \%$ heat inactivated FCS, $2 \mathrm{mM}$ glutamine and 50 units $/ \mathrm{ml} \mathrm{IL-2} \mathrm{(a} \mathrm{generous} \mathrm{gift}$ of the Cetus Corporation, Emeryville, CA). The efficiency of retroviral infection was estimated by determining the ADA enzyme activity of TJF- 2 cells exposed to the SAX vector. A $1 \mathrm{ml}$ aliquot of a cell suspension containing $1 \times 10^{6} \mathrm{TJF}-2$ cells was mixed with $1 \mathrm{ml}$ of SAX supernate; $1 \mathrm{ml}$ of medium containing three times the desired polycation concentration was added to yield the desired final concentration of polycation. Cells were incubated for $2 \mathrm{~h}$, washed twice in phosphate buffered saline (PBS), resuspended in $8 \mathrm{ml}$ of medium, and returned to the incubator. Cells were harvested after 4 days, washed twice in PBS, counted, and a cell lysate was prepared by freeze-thaw. The $\left[{ }^{14} \mathrm{C}\right]$ adenosine assay for ADA activity was performed according to Van der Weyden and Bailey (1978). Results were expressed as nanomoles of inosine produced per $10^{8} \mathrm{cclls}$.

CFU-S Bone marrow from DBA/2J mice was collected and cocultured overnight on $\psi-2$ cells producing the retroviral vector N2 in the presence of polybrene $6 \mu \mathrm{g} / \mathrm{ml}$, protamine $5 \mu \mathrm{g} / \mathrm{ml}$, or no polycation. Treated marrow was then injected into irradiated recipient mice ( 900 rads) and CFU-S were generated as previously described (Eglitis et al., 1985). Foci were harvested on days 10-12 and cell lysates were obtained from individual foci by freeze-thaw. Lysates were analyzed for neomycin phosphotransferase activity using the method of Reiss et al. (1984).

\section{Results}

Effect of protamine sulfate on the infectivity of NIH 3 T3 cells

NIH 3 T3 cells (murine fibroblasts) were exposed to viral supernate containing the SAX vector in varying concentrations of polybrene and protamine sulfate and 


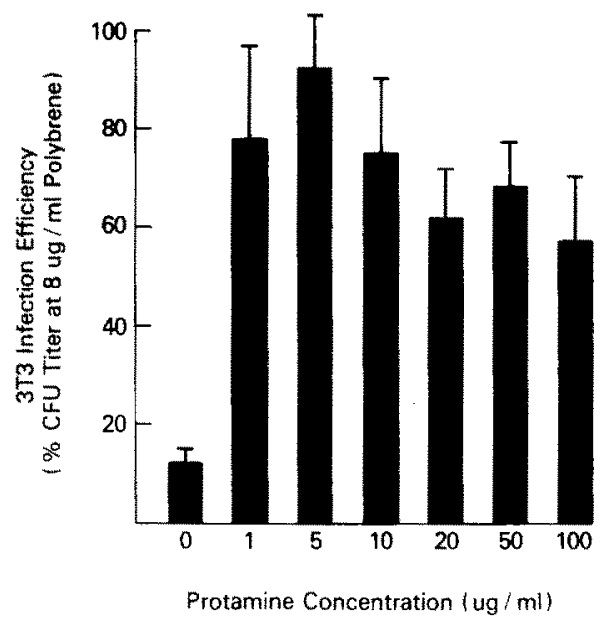

Fig. 2. Effect of protamine sulfate on the infection efficiency of NIH $3 \mathrm{~T} 3$ cells exposed to the retroviral vector SAX. Values represent the viral titer obtained with various concentrations of protamine as a percentage of the viral titer obtained with $8 \mu \mathrm{g} / \mathrm{ml}$ of polybrene.

the viral titer determined using G418 selection. Since the viral supernate and plated cells were constant, variations in viral titer are a reflection of infection efficiency at the particular polycation concentration used. Polybrene has its maximal infection efficiency under this set of conditions at $8 \mu \mathrm{g} / \mathrm{ml}$ (data not shown) resulting in approximately 8 -fold increase in viral titer compared to $3 \mathrm{~T} 3$ cells infected in the absence of polycation. Figure 2 summarizes three experiments and demonstrates the G418-resistance titer obtained with varying concentrations of protamine (as a percentage of the titer obtained with $8 \mu \mathrm{g} / \mathrm{ml}$ of polybrene). On average, protamine at $5 \mu \mathrm{g} / \mathrm{ml}$ yields the highest value: a titer that is $92 \% \pm 11.3$ (SEM) of that obtained with $8 \mu \mathrm{g} / \mathrm{ml}$ of polybrene. The efficiency rate was not increased by using $2,4,6$, or $8 \mu \mathrm{g} / \mathrm{ml}$ of protamine (data not shown).

The titer obtained when both cations are used simultaneously is shown in Table 1. In combination there is little if any increase in effectiveness.

\section{TABLE 1}

Viral titer: combination of protamine and polybrene

\begin{tabular}{llll}
\hline $\begin{array}{l}\text { Polybrene } \\
(\mu \mathrm{g} / \mathrm{ml})\end{array}$ & $\begin{array}{l}\text { Protamine } \\
(\mu \mathrm{g} / \mathrm{ml})\end{array}$ & $\begin{array}{l}\text { Titer } \times 10^{\circ} \\
(\mathrm{CFU} / \mathrm{ml})\end{array}$ & $\begin{array}{l}\% \text { Polybrene } \\
(8 \mu \mathrm{g} / \mathrm{ml})\end{array}$ \\
\hline 8 & 0 & 1.54 & 100 \\
4 & 0 & 1.53 & 99.4 \\
0 & & 1.68 & 109.1 \\
0 & 4 & 1.50 & 97.4 \\
4 & 8 & & 112.3 \\
8 & 4 & 1.73 & 114.3 \\
\hline
\end{tabular}

CFU/ml, colony forming units per $\mathrm{ml}$. 
TABLE 2

ADA activity in infected ADA-deficient human T lymphocytes infected with the SAX retroviral vector

\begin{tabular}{|c|c|c|c|}
\hline Polycation & $\begin{array}{l}\text { Total ADA activity } \\
(\mathrm{nm} \text { inosine/min } \times \\
\left.10^{-2}\right)\end{array}$ & $\begin{array}{l}\text { Total cell number } \\
\left(\times 10^{5}\right)\end{array}$ & $\begin{array}{l}\text { ADA activity/cell } \\
\text { (nm inosine } / \mathrm{min} / 10^{8} \\
\text { cells) }\end{array}$ \\
\hline no polycation & $9.3 \pm 2.7(8.1)^{\mathrm{a}}$ & $42.3 \pm 9.8$ & $2.2 \pm 1.2(5.9)$ \\
\hline polybrene $8 \mu \mathrm{g} / \mathrm{ml}$ & $115.0 \pm 20.6(100)$ & $30.8 \pm 2.0$ & $37.3 \pm 9.2(100)$ \\
\hline protamine $\quad 1 \mu \mathrm{g} / \mathrm{ml}$ & $38.9 \pm 3.8(33.8)$ & $41.4 \pm 4.6$ & $9.4 \pm 0.2(25.2)$ \\
\hline $10 \mu \mathrm{g} / \mathrm{ml}$ & $95.8 \pm 16.7(83.3)$ & $38.5 \pm 11.7$ & $24.9 \pm 11.4(66.8)$ \\
\hline $50 \mu \mathrm{g} / \mathrm{ml}$ & $36.8 \pm 21.4(32.0)$ & $21.6 \pm 5.2$ & $17.0 \pm 6.1(45.6)$ \\
\hline $100 \mu \mathrm{g} / \mathrm{ml}$ & $21.3 \pm 13.6(18.5)$ & $12.5 \pm 4.4$ & $17.0 \pm 5.5(45.6)$ \\
\hline
\end{tabular}

a Value \pm SEM. ( ) represents the percent activity compared to polybrene at $8 \mu \mathrm{g} / \mathrm{ml}$.

\section{Effect of protamine on the infectivity of human $T$ lymphocytes}

The retroviral vector SAX was incubated with human ADA-deficient $\mathrm{T}$ lymphocytes (TJF-2) in the presence of varying amounts of polycations. The level of ADA activity conferred on unselected cells was used as an indication of infection efficiency. The total ADA activity, cell number, and ADA activity per cell four days after infection is presented in Table 2 . The highest total ADA activity was obtained when $10 \mu \mathrm{g} / \mathrm{ml}$ of protamine was used and was $83.3 \%$ of the activity obtained with polybrene. The efficiency rate was not increased by using 5,8 or 20 $\mu \mathrm{g} / \mathrm{ml}$ of protamine (data not shown). The relative distribution of ADA activity

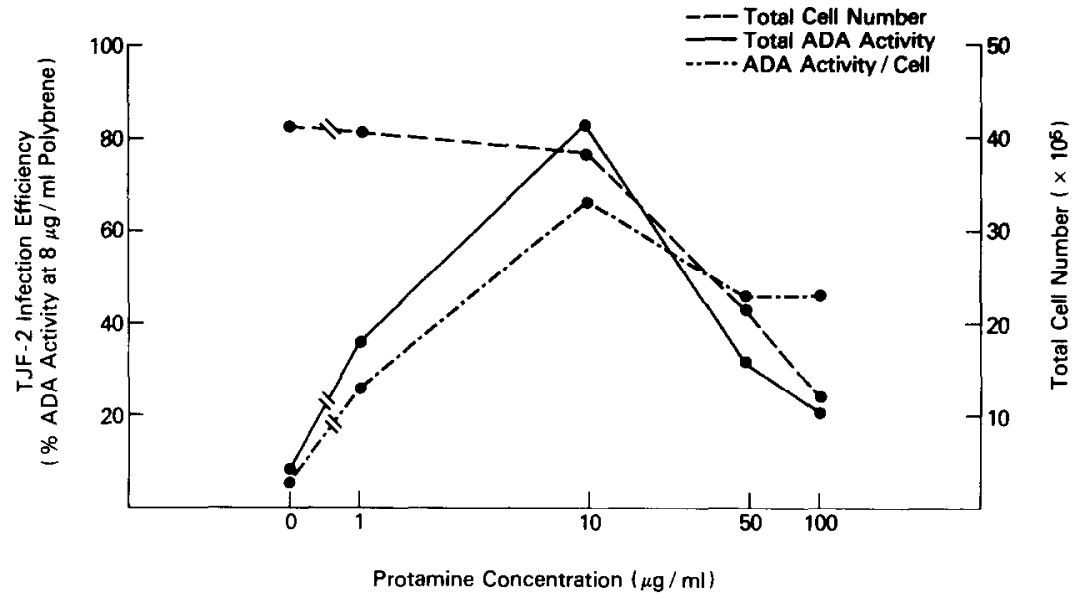

Fig. 3. Effect of protamine sulfate on the growth and infection efficiency of TJF-2 cells exposed to the retroviral vector SAX. Total ADA activity represents the activity obtained from all cells present 4 days after infection of $1 \times 10^{6} \mathrm{TJF}-2$ cells. Total cell number represents the cell number obtained 4 days after infection. ADA activity per cell represents the total activity divided by the cell number. ADA activity is expressed as the percent ADA activity obtained with $8 \mu \mathrm{g} / \mathrm{ml}$ of polybrene. 
for each concentration did not change when the duration of culture was extended to 8 days (data not shown).

Increasing the concentration of protamine above $10 \mu \mathrm{g} / \mathrm{ml}$ led to a significant decrease in the number of cells recovered after 4 days of culture (Fig. 3). Since the initial infection was performed on a constant number of cells $\left(1 \times 10^{6}\right)$, and cells were not selected, the decrease in cell number is a reflection of polycation toxicity. The toxic effects of polycation are similar for polybrene with $8 \mu \mathrm{g} / \mathrm{ml}$ giving the maximal recovery of total ADA and ADA activity per cell (data not shown).

Assuming the level of vector expression is not polycation dependent, ADA activity per cell reflects the ratio of infected to uninfected cells, i.e. the infection efficiency. Total ADA activity is dependent on both the infection efficiency and the amount of toxicity at a particular polycation concentration. As illustrated in Fig. 3 , the ADA per cell peaks at $10 \mu \mathrm{g} / \mathrm{ml}$ and above this concentration the infection efficiency decreases moderately but stabilizes. When considering the total ADA we see a dramatic decrease with concentrations above $10 \mu \mathrm{g} / \mathrm{ml}$ which correlates directly with the decreasing cell number. 'Therefore $10 \mu \mathrm{g} / \mathrm{ml}$ is the protamine concentration that maximizes infection efficiency and minimizes toxicity in this cell type.

While the total ADA activity attained was $83 \%$ of that seen with polybrene, the activity seen per cell represented only $67 \%$ of that obtained with polybrene. This suggests that polybrene may have a slightly higher infection efficiency but is more toxic. Toxicity studies of polybrene on TJF-2 cells support this contention (data not shown).

To determine if the toxic effect was an immediate response, trypan blue viability was performed on TJF-2 and 3T3 cells after a 2 hour incubation with polycation (Table 3). Increasing the concentration of the polycation decreases the viability of TJF- 2 cells but not of $3 T 3$ cells. In an attempt to decrease the toxicity, and possibly increase the infection efficiency, we added neutralizing doses of heparin at the end of a $2 \mathrm{~h} \mathrm{TJF}-2$ cell infection. However, there was no improvement in the viable ccll count or in the amount of $\Lambda \mathrm{DA}$ activity recovered (data not shown).

TABLE 3

Trypan blue viability: $2 \mathrm{~h}$ exposure to polycation

\begin{tabular}{lll}
\hline Polycation & TJF-2 $(\%)$ & $3 \mathrm{~T} 3(\%)$ \\
\hline none & 90 & 98 \\
polybrene $-8 \mu \mathrm{g} / \mathrm{ml}$ & 90 & 98 \\
protamine $-1 \mu \mathrm{g} / \mathrm{ml}$ & 91 & 96 \\
-10 & 88 & 97 \\
-50 & 73 & 87 \\
-75 & - & 97 \\
-100 & 74 & 95 \\
\hline
\end{tabular}


TABLE 4

Neomycin phosphotransferase activity in CFU-S infected with $\mathrm{N} 2$ by cocultivation: effect of polycation

\begin{tabular}{lll}
\hline Polycation & Positive/total $(N)$ & Positive $(\%)$ \\
\hline polybrene & $27 / 38$ & 71 \\
protamine & $30 / 36$ & 83 \\
no polycation & $12 / 21$ & 57 \\
\hline
\end{tabular}

Mouse bone marrow cells were cocultured for $20 \mathrm{~h}$ on $\psi 2$ cells producing the $\mathrm{N} 2$ retroviral vector in the presence of $8 \mu \mathrm{g} / \mathrm{ml}$ of polybrene, $10 \mu \mathrm{g} / \mathrm{ml}$ of protamine or no polycation.

\section{Infection of mouse CFU-S by cocultivation: comparison of polycations}

The effect of polycation on the efficiency of retroviral infection using the cocultivation technique was assessed by measuring the in vivo expression of the retroviral vector $\mathrm{N} 2$ in mouse spleen colony units (CFU-S). As indicated in Table 4 protamine was as effective as polybrene. Infection rates of CFU-S by supernate infection were too low $(<1 \%)$ to be useful for comparison.

\section{Discussion}

The polycation polybrene is routinely used to increase the infection efficiency of both retroviruses and retroviral vectors in vitro. Using expression of retroviral vectors as a measure of infection efficiency we have demonstrated that protamine sulfate can be substituted for polybrene when infecting NIH 3 T3 cells, human T lymphocytes and mouse CFU-S. We have also examined a number of other cell types with similar results (data not shown).

Dextran was initially used to increase murine retroviral infection (Duc-Nguyen 1968) but polybrene has been utilized more recently because of its lower toxicity (Manning et al., 1971). The enhanced infections seen with these cations are presumably through a charge-mediated mechanism that affects virus absorption, penetration or both (Kaplan et al., 1967; Toyoshima and Vogt, 1969). Protamine appears to function in a similar manner since combinations of polybrene and protamine did not increase the efficiency of supernate infection.

The human T cell line TJF-2 showed maximal ADA activity consistently at 10 $\mu \mathrm{g} / \mathrm{ml}$ of protamine and the total ADA produced in an unselected population of TJF- 2 cells was $83 \%$ of that obtained with polybrene. Increasing the protamine concentration above $10 \mu \mathrm{g} / \mathrm{ml}$, and polybrene above $8 \mu \mathrm{g} / \mathrm{ml}$, did not increase the infection efficiency but did decrease the number of viable TJF- 2 cells recovered. Trypan blue exclusion revealed evidence of toxicity after a $2 \mathrm{~h}$ exposure to polycation and the toxic effect was not reversed by heparin. NIH 3 T3 cells did not demonstrate this toxicity suggesting that different cell lines have different sensitivities to polycations. Despite the resistance of NIH 3 T3 cells to the toxic effects, increasing the concentration of polybrene above $8 \mu \mathrm{g} / \mathrm{ml}$ or protamine above 5 $\mu \mathrm{g} / \mathrm{ml}$ did not increase their infection efficiency.

Cocultivation greatly increases the infection efficiency of murine CFU-S over in- 
fections by viral supernate. The addition of polycation in this system has only a small effect on the infection efficiency suggesting that the mechanism of infection may be different than when cell-free supernate is used. Meaningful comparison between the presence or absence of polycation in CFU-S supernate infections was not possible due to the low infection frequency.

When considering retroviral-mediated gene transfer as a means of treating genetic diseases, the safety as well as the efficacy of the proposed procedure must be considered (Anderson and Fletcher, 1980; Anderson, 1984). Potential risks should be minimized and current guidelines for the preparation of biologic materials should be used whenever possible. We have provided an alternative infection procedure that replaces polybrene with a drug currently approved by the FDA for human use. Protamine at a concentration of $5-10 \mu \mathrm{g} / \mathrm{ml}$ should be considered when planning human gene therapy protocols.

\section{References}

Anderson, W.F. (1984) Prospects for human gene therapy. Science 226, 401-409.

Anderson, W.F. and Fletcher, J.C. (1980) Gene therapy in human beings: when is it ethical to begin? New Engl. J. Med. 303, 1293-1297.

Armentano, D., Yu, S., Kantoff, P.W., von Ruden, T., Anderson, W.F. and Gilboa, E. (1987) Effect of internal viral sequences on the utility of retroviral vectors. J. Virol. 61, 1647-1650.

Duc-Nguyen, H. (1968) Enhancing effect of diethylaminoethyl-dextran on the focusforming titer of a murine sarcoma virus (Harvey strain). J. Virol. 2, 643-644.

Eglitis, M.A., Kantoff, P., Gilboa, E. and Anderson, W.F. (1985) Gene expression in mice after high efficiency retroviral-mediated gene transfer. Science 230, 1395-1398.

Gilboa, E., Kantoff, P.W., Eglitis, M.A. and Anderson, F.A. (1986) Transfer and expression of cloned genes using retroviral vectors. BioTechniques 4, 504-512

Kantoff, P.W., Kohn, D.B., Mitsuya, H., Armentano, D., Sieberg, M., Zwiebel, J.A., Eglitis, M.A., McLachlin, J.R., Wiginton, D.A., Hutton, J.J., Horowitz, S.D., Gilboa, E., Blaese, R.M. and Anderson, W.F. (1986) Correction of adenosine deaminase deficiency in cultured human $\mathrm{T}$ and $\mathrm{B}$ cells by retrovirus-mediated gene transfer. PNAS 83, 6563-6567.

Kaplan, M.M., Wiktor, T.T., Maes, R.F. et al. (1967) Effect of polyions on the infectivity of rabies virus in tissue culture: construction of a single-cycle growth curve. J. Virol. 1, 145-151.

Mann, R., Mulligan, R.C. and Baltimore, D. (1983) Construction of a retrovirus packaging mutant and its use to produce helper-free defective retrovirus. Cell 33, 153-159.

Manning, J.S., Hackett, A.J. and Darby, N.B. Jr. (1971) Effect of polycations on sensitivity of BALB/3T3 cells to murine leukemia and sarcoma virus infectivity. Appl. Microbiol. 22, 1162-1163.

Miller, A.D., Trauber, D.R. and Buttimore, C. (1986) Factors involved in production of helper virusfree retrovirus vectors. Somatic Cell Genetics 12, 175-183.

Mitsuya, H., Guo, H., Megson, M. et al. (1984) Transformation and cytopathogenic effect in an immune human T-cell clone infected with HTLV-I. Science 223, 1293-1296.

Reiss, B., Sprengel, R., Will, H. and Schaller, H. (1984) A new sensitive method for qualitative and quantitative assay for neomycin phosphotransferase in crude cell extracts. Gene 30, 211-218.

Toyoshima, K. and Vogt, P.K. (1969) Enhancement and inhibition of avian sarcoma viruses by polycations and polyanions. Virology 38, 414-426.

Van der Weyden, M.B. and Bailey, L. (1978) A micromethod for determining adenosine deaminase and purine nucleoside phosphorylase activity in cells from human peripheral blood. Clin. Chim. Acta $82,179-184$ 